НАУКОВИЙ ВІСНИК

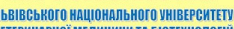

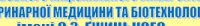
ientific Vetinc messenger of Liviv National University of
vetriary Medicine and Biotechnologies

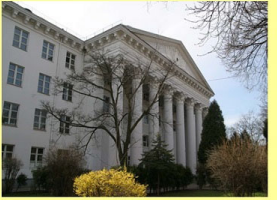

СЕРЯЯ "ЕКОНОМІчН НАУК

Том 22 № 95 2020
Науковий вісник Аьвівського національного університету ветеринарної медицини та біотехнологій імені С.3. Гжицького. Серія: Економічні науки

\author{
Scientific Messenger of Lviv National University \\ of Veterinary Medicine and Biotechnologies. \\ Series: Economical Sciences
}

ISSN 2519-2701 print

https://nvlvet.com.ua/index.php/economy

doi: 10.32718/nvlvet-e9502

UDC 338.43:631.1

\title{
Conception of multifunctional rural areas regional development
}

\author{
P. M. Muzyka ${ }^{1}$, L. V. Goncharenko ${ }^{2}$, D. O. Solomonko ${ }^{1}$ \\ ${ }^{1}$ Stepan Gzhytskyi National University of Veterinary Medicine and Biotechnologies Lviv, Ukraine \\ ${ }^{2}$ Department of Agro-Industrial Development of Lviv State Area Administration, Lviv, Ukraine
}

Article info

Received 31.08.2020

Received in revised form 28.09.2020

Accepted 29.09.2020

Stepan Gzhytskyi National University of Veterinary Medicine and Biotechnologies Lviv, Pekarska Str., 50, Lviv, 79010, Ukraine. Tel.: +38-067-803-60-32

E-mail:myzukapavlo@ukr.net, dmsolom777@gmail.com

Department of Agro-Industrial Development of Lviv State Area Administration, Chornovola Str., 57, Lviv, 79013, Ukraine
Muzyka, P. M., Goncharenko, L. V., \& Solomonko, D. O. (2020). Conception of multifunctional rural areas regional development. Scientific Messenger of Lviv National University of Veterinary Medicine and Biotechnologies. Series: Economical Sciences, 22(95), 10-14. doi: 10.32718/nvlvete9502

Priorities of conception of regional rural areas multifunctional development are revealed in the article. Experience in European Union countries and European Green Deal policy is taken into account for rural areas development in regional level. Priorities of sustainable development policy in rural areas and regional agri-food industry are certainly in ground of strategy development due to cluster initiatives in the Lviv Region. Certainly priorities and advantages of cluster development strategy in rural areas recognition experience and prospects of transborder cooperation initiative. Possibility in farms economic development providing is examined within the framework of clusters for achievement of synergy effect and positive influence on the economic, ecological and social sphere in region. Cluster conception of development is realized in the Lviv Region allowed to provide economic support of farms, develop infrastructural ecosystem of business support and complex to define priorities of multifunctional rural areas development in regional level. Perspective directions of integrated development of craft food producers within the framework in regional clusters at the level of counties in Lviv Area are grounded. Offered approach of institutional development in regional level with the purpose of multifunctional rural areas development with balance between economy, ecological and social constituents within the framework to the cluster for realization of farms competitive edges during the correct keeping of products in the internal market. Certainly priorities of state business support in regional agri-food industry during realization of cluster development initiatives and measures of stimulant influence are for providing modernization changes on principles of Smart Specialization.

Key words: development, conception, rural areas, agri-food industry, cluster, region.

\section{Концепція мультифункціонального розвитку сільських територій регіону}

\author{
П. М. Музика, Л. В. Гончаренко, Д. О. Соломонко
}

${ }^{1}$ Львівський національний університет ветеринарної медицини та біотехнологій імені С. 3. Гюииького, м. Львів, Україна

${ }^{2}$ Департамент агропромислового розвитку Львівської обласної державної адміністрації, м. Львів, Україна

У статті актуалізовано пріоритети концепиії мультифункціонального розвитку сільських територій. Враховано досвід краӥн Свропейського Союзу та політики Свропейського зеленого курсу для розвитку сільських територій на регіональному рівні. Пріоритети політики збалансованого розвитку сільських територій та регіонального агропродовольчого підкомплексу визначено в основі розробки стратегї реалізації кластерних ініціатив у Львівській області. Визначено пріоритети та переваги кластерної стратегії розвитку сільських територій із врахуванням досвіду Львівської області і перспектив транскордонного співробітництва. Розглядається можливість забезпечення економічного розвитку фермерських господарств в рамках кластерів для досягнення ефекту синергії та позитивного впливу на економічну,екологічну та соичіальну сферу регіону. Кластерна кониепція розвитку реалізована у Львівській області дозволила забезпечити економічну підтримку фермерських господарств, розвинути інфраструктурну екосистему підтримки підприємництва та комплексно визначити пріоритети мультифункціонального розвитку сільських тери- 
торій на регіональному рівні. Обгрунтовано перспективні напрями інтегрованого розвитку виробників крафтової продукції в рамках регіональний кластерів на рівні районів Львівської області. Запропоновано підходи до інституційного розвитку на регіональному рівні з метою мультифункціонального розвитку сільських територій із збалансуванням економічної, екологічної та соціальної складових в рамках кластеру для реалізацї конкурентних переваг фермерських господарств при правильному позиціонуванні продукиії на начіональному ринку. Визначено пріоритети державної підтримки суб'єктів господарювання в агропродовольчому підкомплексі регіону при реалізації кластерних розвиткових інічіатив та заходи стимулюючого впливу для забезпечення модернізаиійних змін на засадах смарт-спеціалізації.

Ключові слова: розвиток, концепція, сільські території, агропродовольчий підкомплекс, кластер, регіон.

\section{Вступ}

В умовах кризових тенденцій в національній та світовій економіці, які викликані наслідками поширення пандемічної хвороби COVID-19 на глобальному рівні, принципово підвищується важливість впровадження нових підходів та заходів стимулюючого впливу для розвитку сільських територій.

В Україні на завершальному етапі здійснення реформа децентралізації, яка передбачає суттєву зміну механізмів розподілу бюджетних ресурсів, підвищення відповідальності об'єднаних територіальних громад за забезпечення економічного розвитку сільських територій в рамках розроблених стратегій розвитку громад, що дозволяє максимізувати ефективність використання ресурсного потенціалу регіону.

Реформа децентралізації створила нові передумови для розвитку підприємницької ініціативи в сільських територіях Львівської області, розширення виробництва крафтових продуктів харчування та створення тематичних маршрутів гастрономічного туризму в різних районах регіону.

Аналіз останніх досліджень та публікацій. Питання розвитку сільських територій на регіональному досліджувалися в наукових працях вітчизняних та зарубіжних економістів, зокрема М. Хвесика, М. Ільїної (Khvesyk \& Ilina, 2019), Н. Хомюк, Н. Павліхи (Khomyuk \& Pavlikha, 2019), В. Борщевського, В. Чемериса (Borshchevskyi \& Chemerys, 2015), В. Душки та інших.

Серед зарубіжних науковців питання мультифункціонального розвитку широко висвітлювалося у працях В. Хедігера, К. Кнікел (Hediger \& Knickel, 2009), С. Тодорової, Д. Ікова (Todorova \& Ikova, 2014), а також колективів авторів досліджень (Boody et al., 2005) та (Tohidyan Far \& Rezaei-Moghaddam, 2019).

Mета дослідження полягає у визначенні концептуальних засад мультифункціонального розвитку сільських територій на регіональному рівні із врахуванням прикордонного статусу Львівської області та можливостей для транскордонного співробітництва.

\section{Матеріал і методи досліджень}

Авторами в процесі дослідження використано діалектичні методи пізнання, порівняльного аналізу i емпіричний для комплексного оцінки і аналізу об'єкта досліджень.

\section{Результати та їх обговорення}

У Львівській області одним із важливих пріоритетів регіональної політики економічного розвитку $\epsilon$ підтримка галузей агропродовольчого підкомплексу, що дозволяє забезпечити формування ефективних ланцюгів створення доданої вартості. При цьому важлива увага суспільства приділяється також соціальним очікуванням щодо споживання безпечних продуктів харчування при виробництві яких мінімізується негативний вплив на екологічне середовище і розвиваються сільські території.

Відповідно до концепції мультифункціонального сільського господарства розвиток підприємницької ініціативи в сільських територіях та фермерства повинні враховувати глобальні екологічні виклики для забезпечення розвитку із врахуванням принципів Цілей сталого розвитку ООН.

Вищі навчальні заклади та коледжі аграрного профілю спеціалізації в системі освіти на Львівщині у сучасних умовах орієнтуються на впровадження нестандартних практик налагодження державноприватного партнерства та співпраці із агроформуваннями регіону, дорадчими службами, впровадження елементів дуальної системи освіти, що дозволяє розвивати компетенції для майбутніх молодих фермерів та підвищити технологічний рівень господарювання у вже діючих фермерських господарствах із врахуванням досвіду модернізаційних змін. Саме постійне підвищення рівня освіти фермерів дозволяє їм ефективно впроваджувати сучасні технологічні рішення, маркетингові рішення, уникаючи прямої цінової конкуренції.

Відзначимо, що пріоритетом політики підтримки розвитку агропродовольчого підкомплексу Львівської області є реалізація заходів для стимулювання та підтримки локальних виробників продуктів харчування, а також максимізації синергії їх розвитку із підприємствами туристичної галузі на регіональному рівні. Це, у свою чергу, передбачає стратегічне бачення налагодження взаємодії між суб'єктами підприємницької діяльності на регіональному рівні із метою швидшого подолання наслідків економічної кризи, що зумовлена глобальною пандемією коронавірусної хвороби, що спричинило короткострокове істотне зниженням обсягів торгівлі, вплинуло на розвиток туристичної індустрії.

Зважаючи на тісну економічну інтеграцію регіону iз країнами $\mathrm{CC}$, політика підтримки розвитку фермерських господарств і виробників органічної сільськогосподарської продукції $є$ важливим пріоритетом Стратегії розвитку Львівської області на період 20212027 років (Strategija rozvitku..., 2020). Це особливо актуально із врахуванням пріоритетів нової політики Європейського зеленого курсу, що реалізуватиметься в поточному десятилітті в країнах ЄС та створює широкі можливості для інтеграції та реалізації проек- 
тних ініціатив в політиці розвитку сільських територій, фермерства, органічного сільського господарства.

У Львівській області вагома увага у підтримці розвитку галузей сільського господарства та харчової промисловості області приділяється в рамках проєкту “Стратегії біоекономіки Львівської області як основи для смарт-спеціалізації регіону” (Na L'vivshhini..., 2020).

Із врахуванням політики підтримки малих виробників та фермерів в регіональному агропродовольчому підкомплексі все більше уваги приділяється підтримці виробників крафтової продукції. Крафтові продукти харчування протягом останніх років зайняли важливу нішу на регіональному споживчому ринку, а їх виробництвом займаються, переважно, невеликі фермерські господарства сімейного типу. Більшість підприємств-виробників крафтової продукції активно співпрацюють із готельно-ресторанним бізнесом або самостійно надають туристичні послуги.

У Львівській області значна частина виробників крафтової продукції орієнтується на задоволення нішевих потреб споживачів і готельно-ресторанної сфери, спеціалізуючись на виробництві молокопродуктів, м'ясопродуктів, ягід та фруктів. При підтримці органів державної влади місцеві виробники крафтової продукції формують місцеві бренди, розвивають торгові марки для просування продуктів на внутрішньому ринку. Зокрема, найбільша кількість виробників крафтових сирів зосереджена в Сколівському, Яворівському, Пустомитівському, Турківському та Городоцькому районах. Досить часто на крафтових сироварнях Львівської області проводяться національні та регіональні тематичні майстер-класи із сироваріння, розвивається сфера зеленого туризму в селах.

Актуальною для виробників крафтової продукції є реалізована на регіональному рівні Програма підвищення конкурентоспроможності Львівської області на період до 2020 року. В рамках вказаної програми підприємства харчової промисловості області одержують пільгові кредити або можуть скористатися можливістю розвитку через надання їм інноваційних, маркетингових ваучерів та ваучерів на консалтингові послуги - права на безповоротну фінансову допомогу для суб'єктів господарювання - юридичних осіб та фізичних осіб-підприємців, які перебувають на різних системах оподаткування, на відшкодування частини вартості робіт і послуг згідно із вимогами програми.

Необхідно відзначити, що розвиток виробників крафтових продуктів дозволяє частково вирішити проблему зайнятості сільського населення, оскільки формуються стабільні багаторічні відносини між виробниками сільськогосподарської продукції та суб'єктами господарювання, які здійснюють їх переробку. Це, у свою чергу, гарантує стабільність збуту для фермерських господарств, стимулює розширювати поголів'я тварин і збільшення інвестицій в комплекс технологічно-технічних заходів для підвищення продуктивності свійських тварин, покращення генетичного потенціалу дійного стада та врожайності у галузях рослинництва.
Актуальним питанням у підтримці виробників крафтової продукції у Львівській області є кластеризація виробників в рамках реалізації тематичного компоненту проєкту "Розвиток сільського підприємництва та інфраструктури агротуристичного кластера "Горбогори".

Реалізація проекту дозволила підтримати та стимулювати розвиток альтернативних форм сільського підприємництва в Пустомитівському районі:

- створення інфраструктури збуту продукції місцевих виробників, що вироблятиметься під брендом "Горбогори";

- корчування дерев та окультурення земельних ділянок під вирощування екологічної та органічної сільськогосподарської продукції та прокладання туристичних маршрутів стимулює нові виробництва та запровадження туристичних послуг;

- підведення комунікацій до перспективних для створення кемпінгів ділянок дозволить започаткувати послуги розміщення та харчування автотуристів, побутові послуги;

- розбудова туристичної інформаційної інфраструктури сіл та прокладання туристичних маршрутів сприятиме створенню місцевого турпродукту;

- маркетинг території кластеру та його продукції створює додатковий попит (Strategija ta programa rozvytku..., 2020).

В рамках реалізації вказаного проєкту в Пустомитівському районі створено Сільськогосподарський обслуговуючий кооператив "Горбогори”, відкрито магазин із продажу продуктів локальних фермерів та крафтових виробників. Агроформування регіону, які залучені у ланцюги створення доданої вартості крафтової ніші можуть одержувати фінансову підтримку чи кредити на пільгових умовах за тематичними програмами обласного бюджету від Департаменту агропромислового розвитку та Департаменту економічної політики Львівської обласної державної адміністрації.

Важлива увага проєкту приділяється також популяризації туристичного продукту, формуванню сучасних елементів інфраструктури сільського туризму в Пустомитівському районі Львівської області.

Активними членами проєкту агротуристичного кластера "Горбогори" є ФГ “Західний Равлик", ФГ “Агротем”, Львівська сироварня “Джерсей”, ФГ “Лелик”, домашня міні-ферма “3 Гарбузового Раю”, ФГ “Дві Катерини”, ФГ “Соломея” та інші.

Протягом останніх років в Пустомитівському районі спостерігається позитивна динаміка розвитку галузей сільського господарства. Загалом агровиробничу діяльність в районі здійснює 127 сільськогосподарських підприємств, з яких 113 фермерських господарств та особисті селянські господарства.

Обсяг валової сільськогосподарської продукції в Пустомитівському районі (у постійних цінах 2010 року) зростає протягом останніх років і досяг 619,7 млн грн в 2019 році.

Обсяг виробництва продукції сільського господарства в сільськогосподарських підприємствах Пустомитівського району у 2015-2019 рр. наведено на рис. 1. 


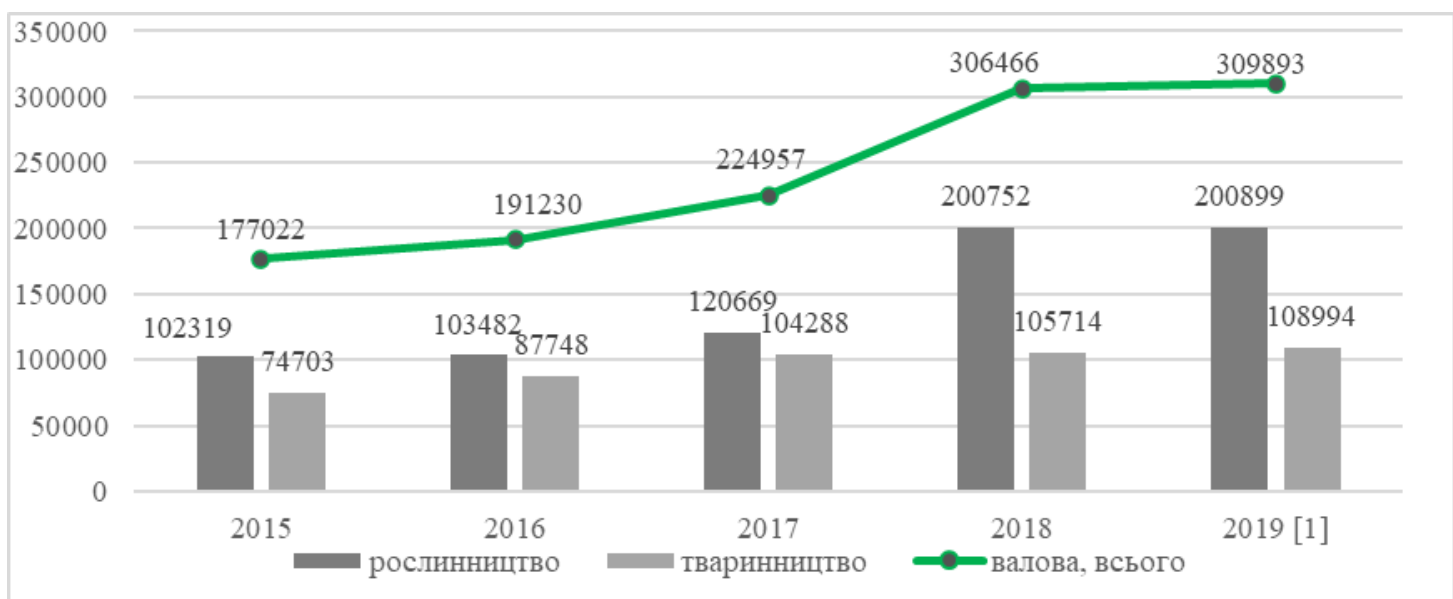

Рис. 1. Валова продукція сільського господарства в сільськогосподарських підприємствах Пустомитівського району Львівської області в 2015-2019 рр. (тис. грн., у постійних цінах 2010 року)*

*Джерело: Департамент агропромислового розвитку Львівської облдержадміністрації

Серед сільськогосподарських підприємств Пустомитівського району основними виробниками плодово-ягідної продукції є ФГ “Первоцвіт", ФГ “Ярко", ФГ “Мальви”, ФГ “Флорина”, ФГ “Баран”, ФГ “Вишенька", ФГ “Файна Бері”, ФГ “Калушка”, ФГ “Ранок”, ФГ “Пролісок”.

Основними виробниками продукції тваринництва в районі є ТОВ “Агролайфтранссервіс", ТОВ “Вівіал”, ФГ “Улар”, ФГ “Дрофа”, ФГ “Кмітливість”, ФГ “АГротем”, ФГ “Радвань-Нова”, ФГ “Західний равлик” та ФГ "Гутвін".

Зміна парадигми розвитку сільського господарства, на думку авторів, із врахуванням сучасних екологічних викликів, орієнтація на інвестиції в людський капітал та сучасні технології інформатизації дозволяють збільшувати прибутковість фермерського бізнесу не за рахунок розширення площ в обробітку, а через ефективне поєднання знань, технологій в агропродовольчому підкомлексі від виробництва до логістичних ланцюгів.

У Львівській області, відповідно до обласних программ, в 2020 році фермери можуть отримати безповоротну фінансову підтримку для реалізації своїх проєктів у сумі 50 тисяч гривень. Фермерські господарства Львівщини також протягом 2016-2020 pp. одержували фінансову підтримку обласного бюджету у формі пільгового кредиту під 5\% річних, які використовуються для розвитку бізнесу. Надається в області протягом останніх років фінансова підтримка виробникам органічної продукції.

\section{Висновки}

На думку авторів, в регіоні доцільно створити Комунальне підприємство Львівської обласної ради “Офіс підтримки фермерських ініціатив”, який надаватиме фермерам всебічну підтримку у реалізації розвиткових проєктів. Серед функцій регіонального oфicy:

- формування інфраструктури підтримки розвитку підприємництва в сільських територіях;

- підтримка розвитку регіональних старт-ап компаній в сфері новітніх агротехнологій;
- співпраця із об’єднаними територіальними громадами у написанні та реалізації проєктів розвитку сільських територій;

- сприяння фермерським господарствам для залученості у реалізації грантових розвиткових проєктів, зокрема у сфері сільського туризму, формування партнерств фермерів та закладів вищої освіти області при реалізації інноваційних проектів Рамкової Програми “Горизонт 2020" та Європейського зеленого курсу;

- орієнтація регіональних програмних проектів на парадигму розвитку людського капіталу та підприємницьких ініціатив на виробництвах агропродовольчого підкомлексу в сільських територіях регіону

Перспективи подальших досліджень. Загалом, можна відзначити, що у Львівській області створено важливі передумови та активно здійснюються заходи для підтримки мультифункціонального розвитку сільських територій на стратегічній основі в умовах зміни поведінки економічних агентів і їх ефективної взаємодії на засадах синергії із туристичною сферою області для забезпечення збалансованого розвитку сільських територій в об'єднаних територіальних громадах. Важлива увага в подальших дослідженнях приділятиметься питанням забезпечення продовольчої безпеки шляхом мультифункціонального розвитку на інноваційній основі регіонального агропродовольчого підкомплексу в рамках реформи децентралізації.

\section{References}

Boody, G., Vondracek, B., Andow, D. A., Krinke, M., Westra, J., Zimmerman, J., \& Welle, P. (2005). Multifunctional agriculture in the United States. BioScience, 55(1), 27-38. doi: 10.1641/00063568(2005)055[0027:MAITUS]2.0.CO;2.

Borshchevskyi, V. V., \& Chemerys, V. A. (2015). Modernizacija socialnoy infrastrukturi sela v konteksti naroshhuvannja ekonomichnogo potencialu silskyh terytoriy ta evoljuciï agrarnogo rinku regionu [Modernization of social infrastructure in rural areas in the context of increasing its economic potential and the evolution of the agricultural market in the region]. 
Rehional'na ekonomika - Regional economy, 1(75), 64-70 (in Ukrainian).

Hediger, W., \& Knickel, K. (2009). Multifunctionality and Sustainability of Agriculture and Rural Areas: A Welfare Economics Perspective. Journal of Environmental Policy \& Planning, 11(4), 291-313. doi: 10.1080/15239080903412453.

Khomyuk, N. L., \& Pavlikha, N. V. (2019). Konceptual'ni pidhody do rozvytku silskyh terytoriy $\mathrm{v}$ umovah decentralizacii [Methodological approaches to analysis of rural territories development in terms of decentralization]. Rehional'na ekonomika - Regional economy, 3(93), 71-78 (in Ukrainian).

Khvesyk, M. A., \& Ilina, M. V. (2019). Parametrizacija ocinjuvannja perspektiv rozvitku silskyh teritorij riznih tipiv [Parametrization of the evaluation of prospects for development of rural areas of different types]. Ekonomika APK, 6, 104-110 (in Ukrainian).

$\mathrm{Na}$ L'vivshini trivaje robota nad Strategieju bioekonomiki oblasti (2020). [The prosecution of Strategy of bioeconomics lasts in Lviv Area]. Lviv State Area Administration: Website. URL: https://loda.gov.ua/news?news_departments $=21 \& i d=5$ 3749 (in Ukrainian).

Strategija ta programa rozvytku agroturystychnogo klasteru "Gorbogory" do 2022 roku (2020). [Strategy and program of development Agritourism cluster "Gorbogory" to 2022 year]. Cluster "Gorbogory": Website. URL: https://horbohory.com.ua (in Ukrainian).

Strategija rozvitku L'vivskoj oblasti na period 2021-2027 rokiv (2020). [Strategy of Lviv Area development during 2021-2027 years] Lviv State Area Administration: Website. URL: https://loda.gov.ua/upload/users_files/ 22/upload/948_Strategija.pdf (in Ukrainian).

Todorova, S., \& Ikova, J. (2014). Multifunctional agriculture: social and ecological impacts on the organic farms in Bulgaria. Procedia Economics and Finance, 9, 310-320. doi: 10.1016/S2212-5671(14)00032-X.

Tohidyan Far, S., \& Rezaei-Moghaddam, K. (2019). Multifunctional agriculture: an approach for entrepreneurship development of agricultural sector. Journal of Global Entrepreneurship Research, 9(1),1-23. doi: 10.1186/s40497-019-0148-4. 